\title{
Two to Tango: An Analysis of Brazilian-Argentine Relations
}

\author{
by Karina Lilia Pasquariello Mariano \\ School of Science and Humanities, São Paulo State University (UNESP-Araraquara), Brazil
}

(SARAIVA, Miriam Gomes. Encontros e Desencontros. O lugar da Argentina na política externa brasileira. Belo Horizonte: Fino Traço Editora, 2012)

66 The Federal Republic of Brazil seeks to form a Latin American community of nations through the economic, political, social, and cultural integration of the peoples of Latin America." So declares the opening paragraph of Article IV of the Fundamental Principles of the Brazilian Constitution of 1988. At first glance, one has the impression that this provision represents a focus of Brazilian foreign policy along with issues such as autonomy, human rights, self-determination, and others in the same Article. The reality, however, is quite different, with the cited text reflecting a time of change when the Brazilian political class was reaffirming its readiness to establish relations on a new footing with its neighbors, especially Argentina.

This repositioning of the Brazilian state in relation to Latin America indicated a willingness to finally overcome Brazil's historic rivalry with Argentina and strengthen the integration process between the two countries. However, due to the lasting image in the public consciousness of binational competition - an image constantly cited as the explanation for the tensions and crises of Mercosur - there was not sufficient political will to overcome the burden of the history between the two nations.

The core of this problem lies in the way the Brazilian state was formed, a process characterized for more than a century by latent confrontation with Argentina over Brazil's regional dominance and international ambitions. The history of this relationship is the topic of Miriam Gomes Saraiva's book Encontros e Desencontros: O lugar da Argentina na Politica Externa Brasileira (Friends and Rivals: Argentina's Role in Brazilian Foreign Policy), which analyzes the development of Brazilian foreign policy vis-à-vis policymakers' 
perspectives on Argentina starting with Brazilian independence and ending with the government of Luiz Inácio Lula da Silva.

Such a long timeframe requires delimitations either that are formal and periodic or that are defined by singular moments relative to the whole. In this book, the story is divided into three phases: distrust and estrangement (1822-1978), distrust and rapprochement (1979-1990), and cooperation and tension (1991-2003).

The first part of the narrative underscores how a sense of rivalry was present even at moments when certain Brazilian governments expressed an intent to establish some kind of rapprochement with Argentina. These efforts led to periods of relative cordiality between the two countries but did not produce concrete results capable of establishing new parameters for relations in the Southern Cone.

This first phase was marked by disputes over the delineation of national boundaries during the first half of the nineteenth century, due especially to Brazil's support for Uruguayan and Paraguayan independence from Argentina. During this period arose the Argentine belief in Brazilian imperialist intentions in the region and a consequent simmering dispute for regional dominance. In Brazil, meanwhile, there emerged a fear of the establishment of an alliance between Argentina and other countries in the region.

During the Paraguayan War this rivalry was put aside in the name of common interest, thereby ushering in a period of cordiality between the two countries, although their international alignments remained very different. While Brazil drew closer to the United States to establish a strategic alliance with this emerging power, Argentina remained closely tied to England and as a result grew politically and economically stronger.

Suspicions remained during the period from the Proclamation of the Republic in Brazil to 1950. Saraiva describes this time as a period of pronounced tension and rivalry against a backdrop of official détente based on a mutual understanding of the need to maintain regional peace. The author highlights the influence of the role of the Foreign Ministry in maintaining a sense of competition between the two nations.

The very structure of the Foreign Ministry as established by the Baron of Rio Branco reflected this tension relative to two aspects of Brazil's international projection: defining boundaries and identifying allies and enemies. For Brazilian diplomacy the U.S. became a strategic ally necessary to ensure Brazil's regional leadership, and so Brazil's relations with its neighbors were driven by the Monroe Doctrine rather than by Bolivarian principles embraced by many other countries, especially Argentina. This divergence further isolated Brazil from other South American nations and increased suspicions of Brazilian imperialist intentions.

Over time, a rivalry arose that went beyond the political sphere and entered the minds of the Brazilian and Argentine people. This rivalry touched a wide range of facets 
of everyday life, but perhaps none more so than soccer. In any case, the book effectively demonstrates how this perception was manipulated or provoked at various points by groups and sectors of society that had no interest in rapprochement with Argentina or that saw such overtures as harmful to their interests.

A good example of this phenomenon was the Perón and Vargas governments' 1950 rapprochement initiative that received strong opposition from the Foreign Ministry and the Brazilian press, which mobilized public opinion and the political class against this project. Overcoming these suspicions and views has not been simple and has required long-term dedication, and Saraiva shows how this process has been carried out for more than half a century in Brazil and Argentina.

The first clear move in this direction was the result of external pressure. In the late 1950s, the Economic Commission for Latin America and the Caribbean (ECLAC) presented economic studies indicating that overcoming underdevelopment in South America would necessarily depend on surmounting rivalries and promoting a process of economic integration.

ECLAC's position stimulated the creation of the Latin American Free Trade Area (LAFTA) in 1960 but did not generate the expected outcomes because in practice there was no significant change in countries' attitudes towards their neighbors, especially in the case of bilateral relations between Brazil and Argentina. The integration that was supposed to promote trust and pave the way for cooperation instead led to increased nationalistic thinking permeated by the idea of autonomous development and the profound distrust of partners.

Saraiva reveals how this attitude changed only in the late 1980s as a result of two key factors: the move of the military governments of the 1970s (especially that of Figueiredo) to review the place of Latin America in Brazil's strategic foreign policy, and Brazil's change in diplomatic outlook in the 1980s that identified Argentina as a strategic partner for Brazil's insertion into the new international context.

This new attitude of the Foreign Ministry drove a change in relations between the two neighbors that was also facilitated, as the author points out, by the convergence of economic and foreign policy and by Brazil's focus on political democratization and the institutional reconstruction of the state. It was at this moment that the Brazilian Foreign Ministry began to defend the idea of regional integration as a viable tactic to promote these countries' industrial development and international engagement.

The repositioning of diplomacy and foreign-policy strategy was reflected in the Brazilian political system as a whole, including the Constituent Assembly, which incorporated into the text of the new constitution the issue of South American integration and cooperative partnerships with neighbors to overcome distrust. In the area of diplomacy, this new 
position materialized in the signing of the Treaty of Integration, Cooperation, and Development between Argentina and Brazil, also in 1988, in an attempt to advance the process initiated by the Program for Integration and Economic Cooperation (PICE) in 1986.

This period of rapprochement and relaxation of tensions between the two nations gave rise to a new stage in relations between Brazil and Argentina beginning in March 1991 with the signing of the Treaty of Asunción that established Mercosur. Relative to PICE, this was a proposal for cooperation that was both broader, in that it incorporated Uruguay and Paraguay, and deeper, in that it created the possibility of a common market in the region.

In practice, this proposed common market was never implemented, since Brazil's Foreign Ministry thought of Mercosur as a means to an end -- the international insertion of Brazil -- and not as an end in itself. This weakened both the integration process and efforts to overcome rivalries and tensions. Argentina remained steadfast in its distrust of Brazilian motives for cooperation between the two countries. This distrust was confirmed in 1999, when Brazil devalued its currency without giving Argentina advance notice, thereby throwing into crisis both its Argentina's economy and the entire integration process, which never recovered from this shock despite partnerships adopted later.

This unilateral Brazilian action instantly revived the flames of suspicion. The Brazilian government sought to soften the impact of its decision by attempting to enhance the weight of South America in Brazilian foreign policy, but this further damaged relations with Argentina because such a repositioning was detrimental to Mercosur.

Even with the advent of the Lula and Kirchner administrations in 2003 and their strong talk of bilateral cooperation, relations between the countries remained strained and revealed contradictions within the Brazilian state. Saraiva points out that while Lula granted more influence to a group linked to academia and to the institutional structure of the Workers Party (PT), which advocated broader and deeper cooperation, he at the same time opted to strengthen the hand of the faction within the Foreign Ministry that pressed for greater autonomy and regional leadership as part of a strategy to make Brazil a world power.

Notwithstanding these difficulties and contradictions, the author points to significant progress in cooperation between the two countries, despite ongoing rivalry, and especially to the Brazilian government's changed view towards Argentina as an important strategic partner for Brazilian foreign policy. 